\title{
ION EXCHANGE IN THE NUCLEAR INDUSTRY (U)
}

by

Jane P. Bibler

Westinghouse Savannah River Company

Savannah River Site

Aiken, SC, USA 29808

An invited paper proposed for

presentation at the

ION-EX'90 Meeting

The Nort East Wales Institute

Cartrefle, Wrexham, Wales, UK

July $9-11,1990$

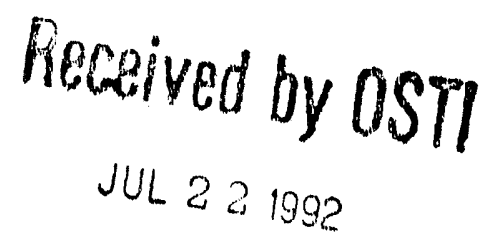

and for publication in the proceedings

\section{DISCLAIMER}

\begin{abstract}
This report was prepared as an account of work sponsored by an agency of the United st tes Government. Neither the United States Government nor any agency thereof, nor any of their employees, makes any warranty, express or implied, or assumes any legal liabiliey or responsibility for the accuracy, completeness, or usefulness of any information, apparatus, product, or process disclosed, or represents that its use would not infringe privately owned rights. Refer. ence herein to any specific commerciai product, process, or service by trade name, irademark. manufacturer, or otherwise does not necessarily constitute or imply its endorsement, recom. manufacturer, of otherw by the United States Government or any agency thereof. The views and opinions of authorb, expressed herein do not neressarily state or reflect those of the United States Government or any agency thereof.
\end{abstract}

The information contained in this document was developed during the course of work under Contract No. DE-AC09-88SR18035 with the U.S. Department of Energy. By acceptance of this document, the publisher and/or recipient acknowledges the U.S.Government's right to retain a nonexclusive, royalty-free license in and to any copyright covering this document along with the right to reproduce and to authorize others to reproduce all or part of the copyrighted document.

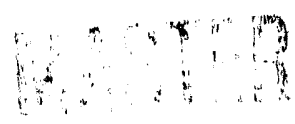




\section{DISCLAIMER}

This report was prepared as an account of work sponsored by an agency of the United States Government. Neither the United States Government nor any agency thereof, nor any of their employees, makes any warranty, express or implied, or assumes any legal liability or responsibility for the accuracy, completeness, or usefulness of any information, apparatus, product, or process disclosed, or represents that its use would not infringe privately owned rights. Reference herein to any specific commercial product, process, or service by trade name, trademark, manufacturer, or otherwise does not necessarily constitute or imply its endorsement, recommendation, or favoring by the United States Government or any agency thereof. The views and opinions of authors expressed herein do not necessarily state or reflect those of the United States Government or any agency thereof.

This report has been reproduced directly from the best available copy.

Available to DOE and DOE contractors from the Office of Scientific and Technical Information, P.O. Box 62, Oak Ridge, TN 37831; prices available from (615) 576-8401, FTS 626-8401.

Available to the public from the National Techncial Information Service, U.S Department of Commerce, 5285 Port Royal Rd., Springfield, VA 22161. 


\title{
ION EXCHANGE IN THE NUCLEAR INDUSTRY
}

\author{
JANE E. BIBLER \\ Westinghouse Savannah River Company \\ Aiken, South Carolina 2.9808 USA
}

\begin{abstract}
Ion exchange is used in nearl: every part of the nuclear fuel cycle - from the purification of uranium from its ore to the final recovery of uranium and transmutation products. Ion exchange also plays a valuable role in the management of nuclear wastes generated in the fuel cycle.
\end{abstract}

\section{INTRODUCTION}

The nuclear indistry encompasses a variety of operations and ion exchange processes play an important role in nearly every operation. Uranium, recovered from its ore, must be purified and concentrated. Enriched uranium is fabricated into fuel elements and placed in nuclear reactors where it produces energy, fission products, and transmutation products. If the fuel cycle is completed, uranium and liseable transmutation products are separated from the fission products and from each other, to be recycled or used elsewhere. Finally, new waste disposal requiremcrts have prompted studies for the use of ion exchange in remediating wastes generated in each of the above operations.

\section{URANIUM PURIFICATION AND CONCWNYRATION}

Triggered by the U.S. nuclear defense efforts in the late 1940's and early 1950 's, extensive pioneering research and development efforts [1-8] laid down the relevant process chemistry of anion exchange purification of lranium. The first actual plant-scale recovery, concentration, and purification of uranium from $\mathrm{H}_{2} \mathrm{SO}_{4}$ ore leach liquors by anion exchange was demonstrated in south Africa in 1952. [9] This demonstration was quickly followed in many countries by construction and operation of similar ion exchange processes for clarified and unclarified (resin-in-pulp) ore leach liquors, both acidic and alkaline carbonate. subsequent investigations of improvements to this earliest 
technology have been concerned with the combination of ion exchange with solvent extraction and with development and testing of new resins and new equipment for countercurrent applications, Recently, ion exchange technology has been directed at the recovery of uranium from mine waters [10] and mill waste streams. [11]

\section{Important Ion Exchange Resins:Types and Propexties}

Strong base Type $I$ resins were the first ion exchange resins used for uranium recovery [6] and still remain as resins of choice in the industry. [12] Typically, the exchange site on a Type I resin is a symmetrical quaternary ammonium ion. Strong base Type II resins use an exchange site similar to Type I resins except that the quaternary ammonium ion is no longer. symmetrical, one methyl group having been substitutea by an ethanolic group. The advantage in sorption offered by Type II resins is due to their lower affinity for $\mathrm{Cl}^{-}$or $\mathrm{NO}_{3}{ }^{-}$compared to Type I resins.[12] Vinyl pyridine strong base resins are effective in removing uranium species from solutions but allow much easier stripping of uranium by $\mathrm{Cl}^{-}$or $\mathrm{NO}_{3}^{-}$than either Type I or Type II resins. Weak base resins used for uranium recovery have tertiary amine functional groups. New waste disposal regulations have precipitated studies of the use of jon exchange for removal of very small concentrations ( 2 to 10 ppm) of uranium from mine waters and waste streams. The resins that have been used in these studies are conventional strong base anion exchangers, weak acid (carboxylic) cation exchangers, and those containing chelating functional groups (e.g. iminodiacteate, amidoxime, picotylamine, aminophosphonic).

The earliest ion exchange uranium recovery operations used gel-type 16-50 mesh anion resin beads in conventional fixed-bed columns. Modern continuous or countercurrent ion exchange (CIX) processes employ macroporous beads of $12-20$ mesh because of their greater resistance to attrition.

\section{Ion Exchange Chamistry}

Dilute $\mathrm{H}_{2} \mathrm{SO}_{4}$ is generally used to leach uranium from ground ores. Acidic sulfate leach liquors contain $\mathrm{UO}_{2}{ }^{2+}, \mathrm{UO}_{2} \mathrm{SO}_{4}$, $\left[\mathrm{UO}_{2}\left(\mathrm{SO}_{4}\right)_{2}\right]^{2-}$, and $\left[\mathrm{UO}_{2}\left(\mathrm{SO}_{4}\right)_{3}\right]^{4-}$ in equilibrium.

$$
\mathrm{UO}_{2}{ }^{2+}+\mathrm{nSO}_{4}{ }^{2-} \leftrightarrow \mathrm{UO}_{2}\left(\mathrm{SO}_{4}\right)^{2-2 \mathrm{n}} \quad \mathrm{n}=1,2 \text {, or } 3
$$

Ion exchange of uranium from these solutions is represented on either strong or weak base anion resins by the following general reaction:

$$
\begin{aligned}
& 4 \mathrm{R}-\mathrm{X}+\mathrm{UO}_{2}\left(\mathrm{SO}_{4}\right)_{3} 4-\leftrightarrow(\mathrm{R})_{4}\left(\mathrm{SO}_{4}\right)_{3}+4 \mathrm{X}^{-} \\
& \text {where } \mathrm{X}=\mathrm{Cl} \text { or } \mathrm{NO}_{3} \text { and } \mathrm{R}=\text { the resin support network. }
\end{aligned}
$$


For mined or ground ores that are high-lime ores ( $\left.158 \mathrm{CaCO}_{3}\right)$, leaching with $\mathrm{H}_{2} \mathrm{SO}_{4}$ would consume very large quantities of the acid and carbonate solutions are, instead, used to leach uranium. (Some in situ leach operations have used ammonium carbonate/bicarbonate mixtures.) [13] Carbonate leach liquors contain the $\mathrm{UO}_{2}\left(\mathrm{CO}_{3}\right)_{3}{ }^{4-}$ ion as the predominating species. This ion is sorbed on the weak and strong base ion exchange resins according to equation (3). The symbols $R$ and $x$ have the same meaning as in equation (2).

$$
4 \mathrm{R}-\mathrm{X}+\mathrm{UO}_{2}\left(\mathrm{CO}_{3}\right)_{3}^{4-} \leftrightarrow(\mathrm{R})_{4} \mathrm{UO}_{2}\left(\mathrm{CO}_{3}\right)_{3}+4 \mathrm{X}^{-}
$$

Frocess variables such as $\mathrm{pH}$, concentrations of sulfate or carbonate, competing anions, temperature, and resin poisons have been extensively documented for the reactions shown in equations (2) and (3) . [5]

When a strong base anion exchange resin has been loaded with uranyl sulfate, it can be efficiently eluted using acidic chloride $\left(0.9 \mathrm{M} \mathrm{NH}_{4} \mathrm{Cl}\right.$ or $\mathrm{NaCl}$ and $0.1 \mathrm{M} \mathrm{HCl}$ or $\left.\mathrm{H}_{2} \mathrm{SO}_{4}\right)$ or acidic nitrate (1.0 $\mathrm{M} \mathrm{NaNO}_{3}$ and $0.1 \mathrm{M} \mathrm{H}^{+}$) solutions. [2] Elution can also be effected using dilute ( 1.0 M) $\mathrm{H}_{2} \mathrm{SO}_{4}$ although with less efficiencey than with chloride or nitrate. Sulfuric acid elution is useful in conjunction with a subsequent solvent extraction process because the eluate can be directly used as feed for that process and the step of converting the resin from the nitrate or chloride form to the sulfate form before the next adsorption cycle can be eliminated. [2]

Acid ellition of sorbed $\mathrm{UO}_{2}\left(\mathrm{CO}_{3}\right)^{4-}$ from anion resins would lead to gas generation and consequent disruption of the resin bed. Thus, elution of this species is accomplished with $\mathrm{NaCl}$ or $\mathrm{NH}_{4} \mathrm{NO}_{3}$ solutions.

After elution of uranium, common resin poisons such as thiocyanate ion, $\mathrm{S}_{2} \mathrm{O}_{6}^{-}$, molybdenum, and iron axe removed by treatment with $\mathrm{NaOH}$ or $\mathrm{NH}_{4} \mathrm{OH}$ solutions. $[2,5]$

\section{Important Ion Exchange Equipment and Methods}

The traditional ion exchange systems designed for collecting and concentrating uranium used fixed-bed columns arranged in a "merry-go-round" array. These systems require clarified feeds for smooth operation. Clarification of feeds after leaching is very expensive, accounting for about half of the operating costs of a uranium miliing plant. [1.4] Costs of the clarification process are driven up by the presence of very small particles (ore slimes) of the ore. One way to lower costs is to first separate the ore slimes from the easily washed and clarified sands fraction of the leachate. Sands fraction wash water and ore slimes are then combined to produce a slurry of up to $30 \%$ suspended solids. Such slurries are used as feedstock for 
resin-in-pulp (RIP) or countercurrent ion exchange processes which have been successful processes for treating unclarified feedstock.

In all CIX systems, the resin bed is fluidized by an upflow stream of feedstock. Continuous ion exchange processes have been described as a major development in ion exchange technology. The success of CIX processes is direct.ly related to the careful experimental and theoretical work of a variety of investigators. [15-22] Three particular fluidized column systems have been used commercially with great success:

NIMCIX System-This system was developed from Cloete-streat: concepts by the National Institute for Metallurgy in South Africa, $[23,24]$

USBM-MCIX System-This system was developed by the U.S. Bureau of Mines. It is used for in situ uranium mining processes. [17-19]

HIMSLEY COLUMN-The most recently proven fluidized bed contacting system, the Himsley column, has seen use in South Africa, Canada, and the U.S. [21,22]

Porter has developed an upflow, multi-tank fluidized bed ion exchange system for Namibia. $[25,26]$ A downflow pulsed-bed ion exchange metrod (Higgins Loop CIX) has been used to recover uranium from copper dump leach liquors at Bingham Canyon, Utah. [11.]

Continuous RIP processes mix resin beads with desanded pulp, separate the uranium-rich beads by a screening step, and then elute uranium from the beads in a separate system, recycling the regenerated beads for reuse in uranium sorption. One or moxe of these operations may be used in any given process. An upflow RIP process has been used to recover uranium in France. [27] Several RIP processes have been used successfully over the past 25 years in uranium milis. [27] All use screen-mix systems, which are the only technology capable of handling medium or high density slurries. No basket RIP systems, developed in the $1980^{\prime} \mathrm{s}$, are in operation. Development of high specific gravity ( $(1.25)$ ion exchange resins would significantly extend the scope of RIP applications.

A combination of ion exchange and solvent extraction, based on pioneering work done at cak Ridge National Laboratory [28], represents the most widely used method for uranium recovery from sulfate ore leach liquors. $[22,29-31]$ The uranium is eluted from ion exchange resins using $\mathrm{H}_{2} \mathrm{SO}_{4}$ and the eluate is used as feed for an extraction by a tertiary amine.

\section{SEPARATION PROCESSES}

Uranium, concentrated in fuel assemblies, undergoes fission, after capturing a neutron in nuclear reactors, to generate fission products, energy, and more neutrons. In power reactors, 
energy is the desired product; in production reactors, the additional neutrons are the desired product because they react to produce new isotopes. The main isotope of the neutron irradiation of natural uranium is ${ }^{239} \mathrm{P}_{1}$, produced when a neutron is captured by ${ }^{238} \mathrm{U}$ (accompanied by two beta decay reactions). The ${ }^{237} \mathrm{~Np}$ isotope is also produced in much lower yields.

After the irradiated fuel elements are removed from the reactor they are stored in cooling basins to allow short lived fission product isotopes to decay. The last step in the nuclear fuel. cycle is the separation of uranium, plutonium, and useful byproducts from each other and from unwanted fission products. Ion exchange cannot compete with solvent extraction in the primary process of uranium recovery, but it is used in several important secondary recovery steps.

\section{Nuclear Fuel Reprocessing}

Throughout the world, reprocessing of nuclear fuels employs some form of the Purex or Thorex processes, solvent extraction processes using tri-n-butylphosphate (TBP) as the extracting agent. Although no reprocessing of power reactor fuels is planned in the U.S., the Savannah River, Hanford, and Idaho Falls defense sites use TBP-based solvent extraction. European, Japanese, and Indian reprocessing facilities use purex or modified Purex processes. The Thorex process was developed to process thorium-based fuels.

In Purex reprocessing, such as at the savannah River site, irradiated uranium is first dissolved in nitric acid and then separated from plutorium and fission products during solvent extraction with TBP. The high activity waste concentrate from the first Purex cycle contains most of the ${ }^{237} \mathrm{~Np}$ and some of the $239 \mathrm{pu}$. It also contains aluminum and most of the fission products. As shown in Eigure 1 [32], the neptunium and plutonium are separated from other ions, except for thorium, by an agitated bed anion exchange step using a strong base resin. This is possible because $\mathrm{Pu}$ (IV) and $\mathrm{Np}$ (IV) both form stable anionic hexanitrato species in the concentrated (7-9M) nitric acid solution.

The Pu and $\mathrm{Np}$ are then eluted with dilute $(0.35 \mathrm{M})$ nitric acid as the $\mathrm{Pu}(\mathrm{IV})$ and $\mathrm{NP}$ (IV) ions and reconverted after elution to the hexanitrato anions with $8 \mathrm{M}$ nitric acid. A second anion column is used to resorb $\mathrm{Pu}\left(\mathrm{NO}_{3}\right) 6^{2-}$ and $\mathrm{Np}\left(\mathrm{NO}_{3}\right) 6^{2-}$. Plutonium is separated from neptunium by elution as Pu(III) with $5.5 \mathrm{M}$ nitric acid, ferrous sulfariate, and hydrazine. Neptunium ion is not: reduced under these conditions and remains sorbed on the resin.

A strong acid cation resin is used next to separate ${ }^{234} \mathrm{Th}$ that is often found with the ${ }^{237} \mathrm{~Np}$. The neptunium is oxidized to $\mathrm{Np}(\mathrm{V})$ in 1-2M nitric acid and, in that oxidation state, is not strongly sorbed by the cation exchanger. Thorium, $\mathrm{Th}^{4+}$, is retained on the resin and is periodically eluted with $\mathrm{NaHSO}_{4}$. Any ${ }^{239} \mathrm{Pu}$ is then recycled back to the rest of the process and 
FIGURE 1

ION EXCHANGE USED IN REPROCESSING URANIUM

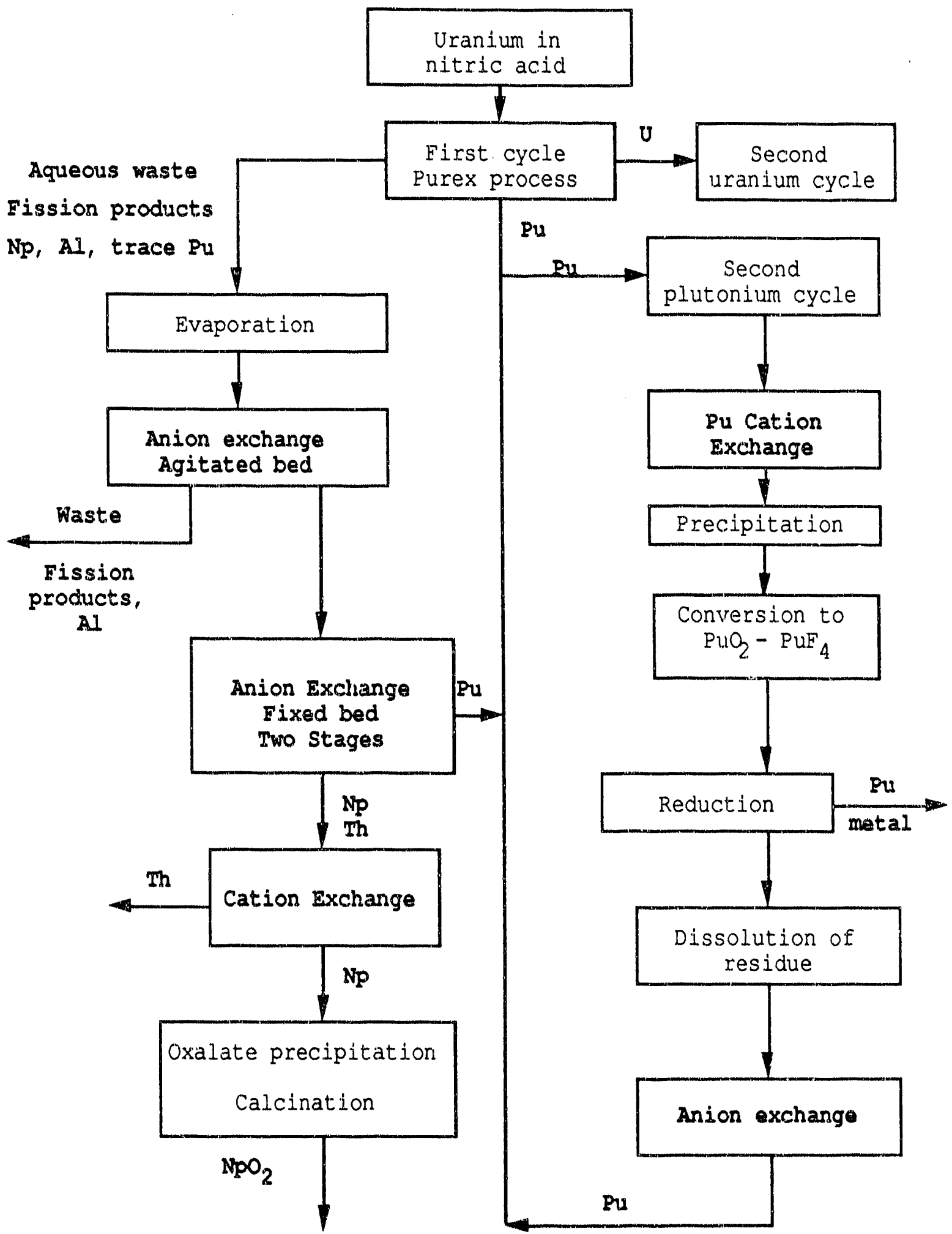


the ${ }^{237} \mathrm{~Np}$ is used in targets for irradiation to make ${ }^{238} \mathrm{Pu}$.

The second cycle of the purex process produces a dilute (1-3 $\mathrm{g} / \mathrm{L}$ ) plutonium stream. Plutonium is concentrated (Figure 1) on a strong acid cation resin after reduction to Pu(III) with hydroxylamine. Sorbed plutonium is eluted with $5 \mathrm{M}$ nitric acid to yield a sc-ution $(40-60 \mathrm{~g} / \mathrm{L})$ that is concentrated enough for subsequent $\mathrm{Pu}$ recovery by precipitation.

When ${ }^{239} \mathrm{Pu}$ metal is produced by reduction using $\mathrm{Ca}$ metal in the recovery process, unreacted plutonium compounds and metal fragments remain in the reaction residue. The residue is treated with concentrated nitric acid to dissolve the plutonium, filtered, and the Pu is sorbed as Pu(IV) on a strong base anion resin. Plutonium collected in this way is recycled to the main process after elution with dilute $\mathrm{HNO}_{3}$.

\section{ION EXCHANGE IN NUCLEAR POWER PLANTS}

A wide variety of reactor designs have been used throughout the world to produce power. Regardiess of the design, the basic operation employs the use of a controlled nuclear reaction to supply energy to produce steam to drive turbine generators. Ion exchange is used extensively to purify water entering and leaving the reactor. $[33,34]$ These applications are briefly noted below:

- Plant makeup water demineralizers usually are strong base or strong acid nuclear grade resins. Nuclear grade resins are distinguished from regular grade resins by their uniform particle size, their purity relative to leachable ions, and their high degree of conversion to the desired ionic form. These very pure resins generate effllient water of the high quality needed to minimize neutron activation product formation and corrosion.

- Reactor coolant water is purified by mixed bed cation and anion exchange systems, normally found in the $\mathrm{H}^{+}$ and $\mathrm{OH}^{-}$forms, respectively. In pressurized water reactors (PWR) the anion resin also serves to rem! borate ion, a nuclear poison.

- Steam condensates are polished using mixed bed, powdered resins that act as filters as well as ion exchangers. Often, deep bed strong acid/strong base systems are used to treat condensate. Evaporator condensates are usually discharged or recycled as makeup water after treatment.

- Contaminated water from fuel pools and other dilute miscellaneous wastes can be treated by ion exchange to yield high purity water.

\section{DECONTAMINATION OF NUCLEAR WASTES}

Waste streams from the reprocessing of nuclear fuels contain 
essentially all of the fission products found in irradiated fuel. The number of variations of the purex or Thorex reprocessing processes used throughout the world leads to an equal number of nuclear wastes, each having its own characteristic properties. It is not possible to consider them all here. Instead, the uses of ion exchange in treatment of some general catagories of nuclear wastes are described. In addition, specific waste treatments of interest involving ion exchange technology are noted.

\section{High Activity Wasto Streams}

Waste streams from fuel reprocessing are acidic in nature. At Savannah River and Hanford the $\mathrm{pH}$ of the waste is adjusted to 12 or greater with $\mathrm{NaOH}$ and the waste is stored in carbon steel. tanks. During aging, insoluble materials precipitate and the primary radionuclide left in the supernate, as the soluble portion of the waste is called, is ${ }^{137} \mathrm{Cs}$.

At Hanford [35], cesium ion was recovered and purified by cation exchange. The first ion exchanger used was a zeolite but this was later changed to a phenolic resin, Duolite ${ }^{\circledR}$ ARC-359. [36] Feed for the process consisted of supernate blended with the product from a phosphotungstate precipitation performed on acid waste. These solutions contained as much as $250 \mathrm{Ci}$ of ${ }^{137} \mathrm{Cs}$ per galion and were about $5 \mathrm{M}$ in sodium ion. After sorption, the sodium ion was preferentially eluted from the resin using $0.25 \mathrm{M}$ ammonium carbonate. Cesium was eluted with a $3 \mathrm{M}\left(\mathrm{NH}_{4}\right)_{2} \mathrm{CO}_{3} / 2 \mathrm{M}$ $\mathrm{NaOH}$ mixture at $60^{\circ} \mathrm{C}$. Ammonium carbonate in the eluate was thermally decomposed and the resulting solution was concentrated by evaporation and sent to storage.

At the Savannah River site [37], a resorcinol/formaldehyde condensation resin has been developed that is capable of selectively sorbing $2.5 \mathrm{E}-4 \mathrm{M} \mathrm{Cs}{ }^{+}$from supernate containing up to $6 \mathrm{M} \mathrm{Na}^{+}$. The cesium can be recovered by elution with $1 \mathrm{M}$ HCOOH or $0.5 \mathrm{M} \mathrm{HNO}_{3}$. Two modes of final disposal of the waste cesium have been proposed:

- Incorporate the eluate containing cesium ion with feed to the glass melter for final encapsulation in glass and then reuse the resin.

- Incorporate spent resin with the feed to the glass melter for final vitrification.

At West Valley Nuclear services Co., a subsidiary of Westinghouse Electric Corp., cleanup has begun on about 550,000 gallons of neutralized purex waste. The initial treatment step involves passing waste supernate through zeolite ion exchange columns to remove $\mathrm{Cs}^{+}$and $\mathrm{Sr}^{2+}$. The loaded zeolite will be combined with washed hydroxide sludge and about 8,000 gallons of acidic Thorex waste, generated during processing of thorium based fuel, for incorporation into glass. [38] 


\section{Low Activity Waste}

High activity wastes are usually concentrated by evaportation to minimize the storage volume required. Condensate from waste evaporators usualiy contains radioactive cesium due to entrainment. Removal of the cesium can be effected using a zeolite or an organic ion exchange resin, depending on the pH of the waste stream and the fate of the decontaminated waste stream. For example, evaporator condensate from nuclear power plants is decontaminated using mixed bed ion exchange in order to generate very pure effluent that can be recycled as makeup water.

At Savannah River Site, condensate is decontaminated first by passage through a zeolite bed and then treatment in an effluent treatment facility. A final polishing step in the effluent treatment uses strong base cation exchange to remove the small quantity of cesium ion that remains in the waste after a reverse osmosis step that preceeds the ion exchange. The cation resin is eluted with $2 \mathrm{M} \mathrm{NaNO}_{3}$ to remove $\mathrm{Cs}^{+}$and the eluate is incorporated in concrete for storage in vaults. [39]

At Oak Ridge National Laboratory, cesium ion is separated from dilute waste by passage through a column of a phenolic/carboxylic acid resin. It is subsequently eluted with $0.5 \mathrm{M} \mathrm{HNO} 3 \cdot[40]$

After the accident at Three Mile Island Unit 2 Nuclear power station (TMI), large volumes of contaminated water remained in the facility that required decontamination. The containment Building sump held approximately 600,000 gallons of contaminated water; about 500,000 gallons were stored in the Auxiliary and Euel Handling building and another 90,000 gallons were in the Reactor coolant system. The primary radionuclides of concern were ${ }^{137} \mathrm{Cs}$ and ${ }^{90} \mathrm{Sr}$ in each case but the activity level in the Auxiliary and Fuel Handling building was less by a factor of ten than that in the other two facilities. A slightly different ion exchange treatinent was used for the two streams.

Waste water from the Auxiliary and Fuel. Handing building was decontaminated by the Epicor II system [41] that was composed of a primary series of carbon steel ion exchange liners (columns) followed by two polishing steps. The liners contained organic ion exchange resins, although some also contained zeolite. The Epicor II system removed approximately 55,000 Ci of gamma emittors, generating 50 highly loaded liners that were disposed of at the commercial waste burial ground at Richland, Washington.

A submerged demineralizer system was used to decontaminate the waste held in the Containment Building sump and the Reactor Core system. Two parallel trains of four ion exchange columns in series were operated in carousel mode while submerged in the reactor fuel pool, which provided shielding. The sorbing medium was a 60/40 mixture of Linde IONSIV ${ }^{\mathrm{TM}} \mathrm{IE}-96$ and A-5I zeolites, designed to remove $\mathrm{Cs}^{+}$and $\mathrm{Sr}^{2+}$, respectively, with nearly 
simultaneous breakthrough of the two radionuclides. The effluent from the zeolite beds was further polished with the Epicor system and stored in tanks for reuse at the TMI facjlity.

Ion exchange technology has been proposed as a method of removing other fission product radionuclides from nuclear wastes. The pertechnetate ion, $\mathrm{TCO}_{4}^{-}$, is readily sorbed on a strong base resin. Large quantities of $4 \mathrm{M}$ nitric acid are required to elute the ${ }^{99} \mathrm{Tc}$ ion from the resin and the process by itself has not been cost effective. Recent work has shown that the pertechnetate ion can be removed from the eluate by sorption onto a weak base resin, allowing recycle of the nitric acid as a cost saving measure. Eiution from the weak base resin with a small volume of $1 \mathrm{M} \mathrm{NaOH}$ completes the isolation of this long-lived isotope from the waste stream. [42]

Chelating resins can be used to complex and retain many cationic radionuclides such as ${ }^{90} \mathrm{Sr},{ }^{60} \mathrm{Co},{ }^{51} \mathrm{Cr}$, and ${ }^{95} \mathrm{Zr}$ that may be found in trace quantities in low activity wastes. The ${ }^{106} \mathrm{Ru}$ (nitrosyl) species found in waste streams have historically resisted efficient isolation by ion exchange. Recent work with somewhat flexible sulfur-containing copolymers [43] gives hope that specially designed functional groups may be able to effect removal of nitrosylruthenium jons from nuclear waste.

On a much smaller scale, except for the case of zeolite ion exchangers, several inorganic exchangers have been used for the sorption and separation of radionuclides. These include the zeolites, synthetic zeolites, hexacyanoferrates, oxides and hydrous oxides, and acidic salts of multivalent metals. [44]

\section{Non-Radioactive Waste-kg}

Fuel elements containing alloys of aluminum with enriched uranium are reprocessed by dissolution in nitric acid using mercuric nitrate as a catalyst. [45] The mercury introduced at. this point ultimately finds its way into both high- and low-activity wastes. Strict regulation of dispensing and storing waste streams containing toxic materials such as mercury has led to studies of ways to isolate and immobilize dissolved mercury from the waste to protect the environment. Duolite ${ }^{\circledR}$ GT-73 cation exchange resin is used entensively at the Savannah River Site [39] to remove $\mathrm{Hg}^{2+}, \mathrm{Hg}_{2}{ }^{2+}$, and dissolved $\mathrm{Hg}^{\circ}$ from dilute waste streams.

\section{OTHER ACTINIDE SEPARATIONS OF INTEREST}

Ion exchange has been used in several applications to separate actinide isotopes produced in special irradiation campaigns.

\section{'ransplutonium Elements}

A decade and a half ago, kilogram quancities of $243 \mathrm{Am}$ and ${ }^{244} \mathrm{Cm}$ and milligram River.[46] At amounts of ${ }^{252} \mathrm{Cf}$ were produced at Savannan about the same time, oak Ridge produced those 
radionuclides as well. as $248 \mathrm{Bk}, 253 \mathrm{Es}$, and $257 \mathrm{Em}$ in their High Flux Isotope Reactor. [47] The heavy traisplutonium elements are made by neutron irradiation of a mixture of pu isotopes $[46,48]$ or a mixture of $2 u, A m$, and $\mathrm{Cm}$. [47] The ion exchange separations of actinides at Loth Oak Ridge and Savannah River were accomplished using high pressure ion exchange. $[46,48-51]$ There are two major advantages in operating high pressure ion exchange for this particular application. First, radiation damage to the resin is minimized because very small resin beads are used, allowing for rapid flow rates. Second, high pressure keeps radiolytic gases, that otherwise would disrupt the bed, in solution.

At Oak Ridge, the lanthanides and actinides were separated from each other on a strong base ion exchanger. Ianthanides were eluted with $10 \mathrm{M}$ LiCl and most of the Am and $\mathrm{Cm}$ were then eluted with 9M Lit3. The rest of the americium and curium and the heavier actinides were eluted with alpha-hydroxyisobutyrate (AHIB). [50] The heavier nuclides elute first because they form more stable complexes with AHTB.

The Savannah River process used displacement development, similar to that used at Hanford [52] to purify Am, on cation exchange resin to effect separation and purification. The lanthanides and actinides were first surbed on the resin column behind a barrier band of zinc ion. Development of the band with diethylenetriaminepentaacetlo acid (DTPA) moved the more stable actinide complexes to the front of the band, leaving the lanthanides behind. The actinides were resorbed on the resin when the band reached the zinc because zinc forms an even more stable complex with DTPA. The net result was that the astinides separated into discrete bands on the resin. They were eluted, resorbed and developed on a series of smaller columin, and finaliy eluted in very pure form.

\section{Concentration of 2330 from $232 \mathrm{Th}$ Irradiation Froducts}

Neutron irradiation of $232 \mathrm{Th}$ produces $233 \mathrm{U},[53,54]$ The two isotopes are separated from each other by the Thorex solvent extraction process using TBP. The uranium stream is concentrated by sorption of $233 \mathrm{U}$ on a strong acid cation resin followed by elution with a $\mathrm{NH}_{4} \mathrm{NO}_{3} / \mathrm{HNO}_{3}$ mixture.

\section{$241_{\text {Am }}$ rom Aged $241_{\text {Pu }}$}

A product of the beta decay of 24 ipu is $241 \mathrm{Am}$, which is used in commerctal applications such as smoke detectors, thickness gauging, and oil weli logging. [55] The separation of plutonium and americium is possible by solvent extraction $[56,57]$, molten salt extraction [55], or precipitation. [58] Each of these separation processes, however, must be coupled with at least one ion exchange process step. Cation exchange allows a preliminary separation of $\mathrm{PL}$ (III) and $\mathrm{Am}$ (III) from ionic impurities of +1 or +2 charge. Also, anion exchange of $\mathrm{Pu}\left(\mathrm{NO}_{3}\right)_{6}{ }^{2-}$ from concentrated nitric acid solution effects its separation from Am(III). 


\section{REFERENCES}

1. Uranium in South Africa, 1946-1956," Associated Scientific and Technical. Societies of South Africa, Jchannesburg, South Africa (1957).

2. Merritt, R. C., "The Extractive Metallurgy of Uranium," Colorado School of Mines Research Institute, Golden, co $(1.970)$.

3. Jacobs, S. A., S. J. Schnexailder, C. Urban, Jr., T. C. Smith, and D. E. Gonzales, "Recovery of Low-Level, Dissolved Uranium Values from Treated Mine Waters" in Broc. Int confe on Uranium Mine Waste Risposal (1980) .

4. Brooke, J. N., "Uranium Recovery from Copper Leaching Operations," Min. Congress J., 63(8) 38-41, August 1977.

5. Gittus, J.H.,"Uranium", Butterworths, Washington, DC, p. 51 (1963).

6. Kunin, R., "Ion Exchange Resins," John Wiley \& Sons, Inc., New York, NY (1958).

7. Browning, S. J., "Processing of Uranium Ores," Australian Min., 48 (1972).

8. Kennedy, R. H., "Status Report from the united States of America," in Processing of Low-Grade Uranium Ores, Vienna, 1966, IAEA, Vienna (1967).

9. Phillips, C. R. and Y. C. Poon, "Status and Euture Possibilities for the Recovery of Uranium, Thorium, and Rare Earths from Canadian Ores, with Emphasis on the Problem of Radium: Pt. 2, Solvent Extraction and Ion Excharge," Min. Sci. Eng., 12 (1980).

10. Himsley, A., "Recovery of Uranium by Ion Exchange

Process," in Extractive Metallurgy of Uranium, a Short Course, Dept. of Met. and Mat. Sci., University of Toronto and Met. Soc. of Canad. Inst. of Min. and Met., Hydromet. Section (1978).

11. "Uranium Extraction Technology." OECD Nuclear Energy Agency and IAEA, Paris, Erance (1983).

12. McGarvey. F. $X$, and J. Ungar, "The Influence of Resin Eunctional Group on the Ion-Excharge Recovery of Uranium., J.Soutin African Inst. Min. Met. , 93 (1981).

13. Naden, D. ard M. R. Bandy, "Choice and Design of Solid Ion Exchange Plants for Recovery of Uranium," I Chem. Bjotechnol., 29 (1979).

14. Sloete, F.I.D., "The Relix Process for the Rfisin-in-Pulp 
Recovery of Uranium," I. South African Inst, Min. Met., 81,66 (1991).

15. Cloete,E.L.D. and Streat,M, U.S. Patent 3,551,118 (1970).

16. Streat, M. and R. Y. Qassim, "Recovery of Uranium from Unclarified Iuiquors by Ion Exchange," in Pres. Int. Symp. en Hydromet (1973).

17. George, D. R. and J. B. Rosenbaum, "New Developments and Applications of Ion Exchange Techniques for the Mineral Industry," in Rrec. Conf. en Ion Exchange in the precess Industries, Londen, July 1976, Soc. Chem. Ind., London $(1976)$.

18. Traut, D. E., I. L. Nichols, and D. C. Seidel, "Design Requirements for Uranium Ion Exchange from Ammonium Biocarbonate Solutions in a Fluidized System," U.S. Bureau of Mines Report RI 8280, Washington, DC (1978).

19. Traut. D. E., I. L. Nichols, and D. C. Seidel, "Design Requirements for Uranium Ion Exchange from Acidic Solutions in a Eluidized system," U.S. Bureau of Mines Report RI 8282, Washington, DC (1978).

20. Himsley, A., "Performance of Himsley Continuous Ion Exchange System," in Prec. Symp on Hydromet. Manchester, England, July 1981, Soc. Chem. Ind., London (1981).

21. Himsley, A. and E. T. Farkas, "Operation and Design

Details of a Truly Continuous Ion Exchange system," in Prece conf, on the Theery and Practice of Ion Exchange, Cambridge, England, July 1976, Soc. Chem. Ind., London (1976).

22. Higgins, I. R., "Update of Chem-Seps Continuous Ion Exchange Operation Relations to Uranium Recovery," in Rrec. South Texas Uranium Sem. 1979, AIME, New York (1979).

23. Haines, A. K., "The South African Programme on the Development of Continuous Fluidized Bed Ion Exchange with Specific Reference to its Application to the Recovery of Uranium," in S. Africa Inst. Min. and Met. Orange Eree State colloguium, (November 1977).

24. Nico1, D. I., "Design snd Operating Characteristics of the NIMCIX Contactor," in Rros. Annual Conf. Metallurgists, Can. Inst. Min., Montreal, Canada (1978).

25. Porter, R.R. and Rössing Uranium Ltd., U.K. Patent $1,382,450$.

26. Wylie, R. J. M., "Rössing Uranium Reaches Rated Production," Werld Mining, 52 (1979). 
27. Simorisen, H.A., D.W. Boydell, and H.E. James, "The Impact of New Technlogy on the Economics of Uranium Production from Low-Grade Ores," in 5th Int. Symp. of Uranium Soc., London, September 1980, Westbury House, London (1981).

28. Crouse,D.J. and K.B. Brown, "Amine Extract Process for Uranium Recovery from Sulfate Liquor, Vol. I., ORNL-1959 (1955).

29. Eisher, J. W. and A. J. Vivjurka, "Combined Ion-Exchange Solvent Extraction Process (ELUEX) for Ammonium Diuranate Production," in Proc. Conf. on Ion Exchange in the Process Industries, London, England, July 1969, Soc. Chem. Ind., London, , 163 (1970).

30. Gilmore, A. J., V. M. MCNamara, H. W. Parsons, and R. Semard, "Production of High Purity Ammonium Diuranate by the Sulphuric Acid Elution - Amine Extraction Process," Mines Branch Investigation Report IR-60-95, Canada Dept. of Mines and Technical Surveys, Ottawa, Canada (1960).

31. Lloyd, P. J., "Solvent Extraction in the South African Uranium Industry," J. South African Inst. Min. Metald., 465 (1962).

32. Shulz, W.W., Wheelwright, E.J., Godbee, H., Mallory, C.W., Burney, G.A., and Wallace, R.M., "Io.l Exchange and Adsorption in Nuclear Chemical Engineering", Proc. Conf. on Progress and Prospects in Adsorption and Ion Exchange, 75 th Annual Meeting of the American Institute of Chemical Engineers, Washington, D.C., 1983.

33. Radwaste Management Workshop, New Orleans, LA, January $12-14,1977$.

34. Short Course: "Radioactive Waste Management for Nuclear Power Reactors and Other Facilities," Alexandria, VA, May $2,-6,1983$.

35. Larson, D.E. and P.W. Smitr, "reatment of Hanford Nuclear Processing Wastes to Permit Lohg-Term Storage," ARH-SA-51 (1.969).

36. Schulz, W. W., "Distribution Data for Various Cs, Sr, and TC Sorbents," Atlantic Richfield Hanford Company Quarterly Report, ARH-ST-110D; pp. 34-37 (1975).

37. Bibler, J.P., Wallace, R.M., and Bray, L.A., "Testing a New Cesium-Specific Ion Exchange Resin for Decontamination of Alkaline High-Activity Waste", to be presented at the 1990 Waste Management Meeting, Tucson, AZ, February 25-March 1, 1990.

38. Barnes, S.M., Pope, J.M., and Chapman, C.C., "Three Year's Progress of the West Valley Demonstration Project Vitrification System", in Waste Management Eighty Eight, 
T.G.Post, Ed., vol.2, pp 195-202, 1988.

39. Bibler, J.P., and Wallace, R.M., "Ion Exchange Processes for clean-up of Dilute Waste Streams by the F/H Effluent Treatment Facility at the Savannah River Plant", Recent Developments in Ion Exchange-Proceedings IONEX'87, P.A.Williams and M.J.Hudson, Eds., pp 173-180, 1987.

40. King, I. J. and Ichikawa, M., "Pilot Plant Demonstration of the Decontamination of Low-Level Process Wastes by a Recycle Scavenaing-Precipitation Ion-Exchange Process," ORNL-3863 (1965).

41. D'Amrosia, J. T., "Three Mile Island Waste Management, a DOE Perspective," presented at the Americar Institute of Chemical Engineers 1.981 Sunmer National Meeting, August 19,1981 .

42. Walker, D.D., Bibler, J.P., Wallace, R.M., Ebra, M.A., and Ryan, J.P.,Jr., "Tecnetium Removal. Processes for Soluble Defense High-Level Waste", Symposium Proceedings,

Materials Research Seciety, C.M.Jantzen, J.A.Stone, R.C.Ewing Eds., vol. 44, pp 810-809, 1986.

43. Hua'son, M.J. and Dyer, A., "The Use of Coordinating Copolymers to Extract ${ }^{106}$ Ru from Simulated Nuclear Wastes", Solvent Extraction and Ion Exchange in the Nuclear Fuel Cycle, D.H.Logsdail and A.L.Mills Eds., pp 157-168, 1985.

44. Hooper, E.W., "The Application of Inorganic Ion Exchangers to the Treatment of Medium Active Effluents", solvent Extraction and Ion Exchange in the Nuclear Euel cycle, D.H.Logsdail and A/L/Mills Eds., PP 157-168, 1985.

45. Hyder,M.L., et al, "Processing of Irradiated, Enriched Uranium Fuel at the Savannah River Plant", DP-1500, 1979.

46. Burney, G. A., "Separation of Maro-Quantities of Actinide Elements at Savannah River by High Pressure Ion Exchange," Sep. Sci. Technol. 15, 763 (1980).

47. King, I. J., J. E. Bigelow, and E. D. Collins, "Experience in the Separation and Purification of Transplutonium

Elements in the Transplutonium Processing Plant at Oak Ridge National Laboratory" in Transplutonium Elements = Production and Recovery, J. D. Navatril and W. W. Schulz, Eds., American Chemical Society, Washington, DC, pp. 1.34-145 (1981).

48. Lowe, J. T. . W. H. Hale, Jr., and D. F. Hallman, "Development of a Pressurized Cation Exchanger Chromatographic Process for separation of Transplutonium Actinides," Ind. Eng. Chem. Process Design Develop. 10, 131 (1971).

49. Collins, E. D., D. E. Benker, F. R. Chattin, P. B. Orr, 
and G. R. Ross, "Multigram Group separation of Actinide and Lanthanide Elements by LiCl-Based Anion Exchange," in Iransplutonium Elements - preduction and Recovery, J. D. Navatril and W. W. Schulz, Eds., American Chemical

Society, Washington, DC, pp. 148-160 (1981).

50. Benker, D. E., F. R. Chattin, D. E. Colins, J. B. Knauer, P. B. Orr, R. G. Ross, and J. T. Wiggins, "Chromatographic Cation Exchange Separation of Decigram Quantities of Californium and other Transplutonium Elements" in Transplutonium Elements - Production and Recovery, J. D. Navatril and W. W. Schulz, Eds., American Chemical Society, Washington, DC, pp. 161-171 (1981).

51. Campbell, D. O., "The Application of Pressurized Ion Exchange to the Separations of Transplutonium Elements," in Iransplutonium Elements - Production and Resovery, $J$. D. Naratril and $W$. W. Schulz, Eds., American Chemical Society, Washington, DC, pp. 190-201 (1981).

52. Wheelwright, E. J., "Kilogram Scale Purification of Americium by Ion Exchange," Sep. Sci. Technel. 15, 783 (1980).

53. Prout, W. E. and A. E. Symonds, "Recovery of $23: \mathrm{U}$ from Irradiated Th Oxide and Metal," DP-1036 (1967).

54. Burney, G. A., "Cation Exchange Concentration of Aqueous ${ }^{233} \mathrm{U}$ Nitrate and Conversion to $233 \mathrm{UO}_{3}, " \mathrm{DP}-1047$ (1966).

55. Knighton, J. B., P. G. Hagan, J. D. Navatril, and G. H. Thompson, "Status of Americium-242 Recovery at Rocky Elats Plant" in Transplutenium Elements - Production and

Recevery, J. D. Navatril and W. W. Schulz, Eds., American Chemical. Society, Washington, DC, pp. 53-74 (1981).

56. Gray, L. W., G. A. Burney, T. A. Reilly, T. W. Wilson, and J. M. McKibben, "kecovery of Am-241 from Aged Plutonium Metal," in Transplutonium Elements - Production and

Recevery, J. D. Navatril and W. W. Schulz, Eds., American Chemical. Society, washington, DC, pp. 93-108 (1981).

57. Doto, P. C., I. E. Bruns, and W. W. Schulz, "Solvent Extraction Process for Recovery of Americium-241 at Hanford" in Transplutonium Elements - Production and Recovery, J. D. Navatril and W. W. Schulz, Eds., American Chemical Society, washington, DC, pp. 109-128 (1981).

58. Ramsey, H. D., D. G. Clifton, S. W. Hayter, R. A. Pennman, and E. L. Christensen, "Status of Americium-241 at Los Alamos National Laboratory," in Transplutenium Elements Rreduction and Recovery, J. D. Navatril and W. W. Schulz, Eds., American Chemical Society, Washington, DC, pp. 75-91 (1981). 

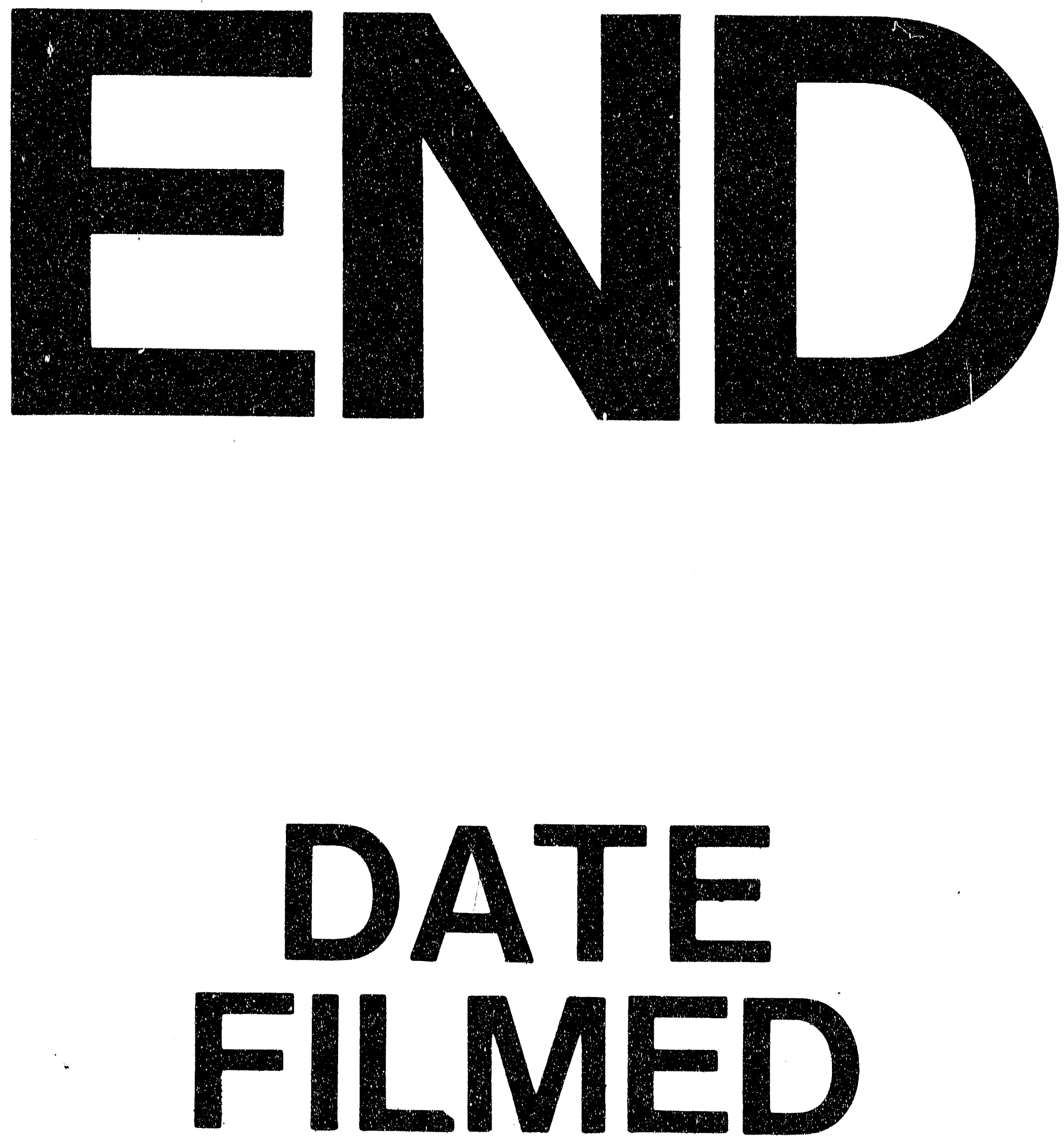

衰

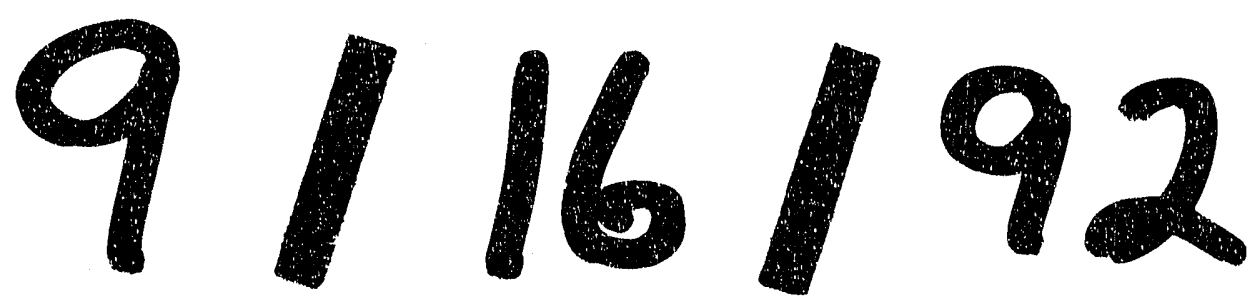


